\section{idenotiune}

Jurnal Kajian Manajemen Dakwah

\title{
Intensitas Menonton Video Dakwah melalui Media Platform Online dengan Tingkat Religiusitas
}

\author{
Pipir Romadi ${ }^{1}$ \\ ${ }^{1}$ Universitas Islam Negeri Sultan Syarif Kasim Riau \\ Email: pipir.romadi@uin-suska.ac.id
}

\begin{abstract}
Religiosity is a one thing are important in a live of people. Religiosity is beliefs that contain values in guiding life. One thing can the power up of religiosity is watching dakwah video from platform online media intens. The study aims to determine the correlation between intensity of watching dakwah video from platform online media with religiosity in students. Population of this study is 100 students of UIN Suska Riau. Total subjects are 100 students and determined by simple random sampling method. Research data collection used a intensity of watching from Ajzen (2005) and Muslim Religiosity scale from Mohd Mahudin, N. D., dkk (2016). Analysis method used rank spearman correlation with correlation coefficient value is 0,494 and $p=0,000(p<0,05)$. The result shows there is a significant correlation between intensity of watching dakwah video from platform online media with religiosity in students. There is a relationship between aspects of appreciation, duration and understanding with religiosity in individuals while the frequency aspect is not related to religiosity. This means that aspects of comprehension, duration and understanding have an effect on increasing religiosity in individuals, while the frequency aspect has no effect.
\end{abstract}

Keywords: Platform Online, Religiusitas

\begin{abstract}
Abstrak: Religiusitas merupakan suatu hal yang penting dalam kehidupan individu. Religiusitas merupakan keyakinan yang berisi nilai-nilai dalam memedomani kehidupan. Salah satu hal yang dapat meningkatkan religiusitas adalah dengan menonton video dakwah melalui media platform online secara intens. Penelitian ini bertujuan untuk mengetahui hubungan intensitas menonton video dakwah melalui media platform online dengan tingkat religiusitas pada mahasiswa. Populasi penelitian adalah mahasiswa UIN Suska Riau. Sampel berjumlah 100 orang mahasiswa dengan menggunakan teknik simple random sampling. Pengumpulan data penelitian menggunakan skala Intensitas Menonton dari teori Ajzen (2005) dan Skala Religiusitas Muslim dari teori Mohd Mahudin, N. D., dkk (2016). Metode analisis menggunakan korelasi rank spearman dengan nilai koefisien korelasi sebesar 0,494 dan $\mathrm{p}=0,000(\mathrm{p}<0,05)$. Hasil penelitian menunjukkan bahwa intensitas menonton video dakwah melalui media platform online berhubungan dengan tingkat religiusitas pada mahasiswa. Terdapat hubungan antara aspek penghayatan, durasi dan pemahaman dengan religiusitas pada individu sedangkan aspek frekuensi tidak berhubungan dengan religiusitas. Artinya aspek penghayatan, durasi dan pemahaman memberikan pengaruh terhadap meningkatnya religiusitas pada individu, sedangkan aspek frekuensi tidak memberikan pengaruhnya.
\end{abstract}

Kata kunci: Platform Online, Religiusitas

\section{Pendahuluan}

Ide-ide agama, dasar-dasar keyakinan dan pokok-pokok ajaran agama yang termasuk kedalam komitmen beragama pada dasarnya telah diterima oleh seseorang di periode masa kanak-kanak. Hal ini sesuai dengan pernyataan yang diberikan oleh Zakiyyah Darajat (2003) yaitu apa yang telah diterima dari kecil maka itulah yang menjadi keyakinan individu pada 
masa remaja melalui pengalaman-pengalaman yang dirasakannya. Hal inilah yang diyakini sebagai religiusitas individu.

Pentingnya religiusitas bagi remaja adalah sebagai bentuk pengendalian diri. Ketika seseorang telah menganggap bahwa agama yang dianutnya merupakan jalan yang membawanya pada kebenaran serta yakin akan ajaran agama tersebut, maka keyakinan itu akan dipertahankan hingga akhir. Sarwono (2011) sendiri menyatakan bahwa moral dan religi mampu mengendalikan diri remaja untuk menghindari hal-hal negatif dan membawanya pada perilaku positif. Hal inilah yang nantinya berhubungan dengan tingkat religiusitas seseorang.

Tingkat religiusitas yang dimiliki seseorang individu dapat mengantarkannya mencapai kesejahteraan subyektif dikarenakan keyakinan yang dimilikinya (dimensi ideologi), baik terhadap Allah SWT, malaikat, rasul, kitab suci Al-Qur'an, qadha dan qadar akan melandasi cara berfikir, bersikap dan berperilaku individu. Keyakinan sepenuh hati yang dimiliki oleh individu akan menghasilkan perasaan positif dalam dirinya dan berusaha untuk menjauhkan diri dari perasaan negatif sehingga ia akan selalu merasa berkecukupan, karena ia yakin yang mengatur hal baik dan buruk yang datang kapadanya adalah Allah SWT.

Religiusitas seseorang apabila baik maka akan membawa pengaruh positif didalam hidupnya, individu tidak akan mudah terpengaruh oleh hal-hal yang akan merugikan dirinya namun sebaliknya, individu dengan tingkat religiusitas yang kurang baik maka akan mudah terpengaruh oleh pergaulan dan hal-hal yang berbau negatif. Salah satu faktor yang dapat mempengaruhi tingkat religiusitas seseorang adalah informasi yang didapatkan oleh individu tersebut.

Saat ini, manusia pada zaman modern pasti tidak asing jika mendengar kata-kata internet. Teknologi komunikasi dan informasi yang terus berkembang telah menghadirkan internet sebagai salah satu bentuk inovasi yang dapat membantu manusia dalam menjalankan aktivitasnya sehari-hari. Internet tidak hanya digemari oleh para remaja, namun orang dewasa juga menggunakan internet di dalam kehidupan mereka karena saat ini penggunaan internet sangat dibutuhkan dalam kehidupan seseorang.

Internet bagi manusia pada zaman modern ini sangat bermanfaat bagi kehidupan. Pengguna internet dapat memanfaatkan perangkat lunak web-browsing untuk mengakses berbagai informasi yang ada di internet. Pengguna internet dapat mencari berbagai informasi dari yang berkaitan dengan pekerjaan, pendidikan, hobi, bisnis, bahkan transaksi jual beli juga saat ini bisa dilakukan melalui internet (Soetjipto, 2005).

Manfaat lain yang juga dapat dirasakan oleh pengguna internet adalah dengan adanya akun-akun media platform online seperti Facebook, Twitter, Instagram, YouTube dan media platform lainnya (Sikape, 2014). Saat ini media platform online tidak hanya bisa dilakukan melalui komputer namun juga dapat diakses melalui Smartphone atau telepon genggam dengan aplikasi android. Aplikasi yang dapat digunakan juga semakin beragam sehingga pengguna internet tidak perlu repot-repot untuk pergi ke warung internet atau menggunakan komputernya. Pengguna internet dapat menggunakan smartphone dengan mengaktifkan data seluler yang sebelumnya kartu pengguna telah terisi kuota internet. Selain paket data, jaringan internet pada smartphone juga bisa diaktifkan melalui WiFi (wireless). 
Namun, selain dari manfaat juga terdapat dampak yang diambil dari penggunaan internet. Individu bisa lupa waktu jika sudah dihadapkan dengan yang namanya smartphone yang saat ini terdapat istilah generasi menunduk. Individu akan lebih fokus kepada hal-hal yang menyenangkan dibanding hal yang bermanfaat. Contohnya dengan adanya aplikasi media platform online yang menghadirkan berbagai fitur menyenangkan seperti media sosial, kemudia aplikasi video yaitu YouTube dan sebagainya. Berbagai aplikasi yang ditawarkan dan kemudahan yang didapat membuat individu kehilangan fokus terhadap kehidupan nyatanya.

Salah satu pengguna yang menikmati berbagai kemudahan yang diberikan oleh adanya dunia internet ini adalah mahasiswa. Mahasiswa yang merupakan dalam tahap perkembanannya berrada pada usia remaja dan dewasa awal pastinya lebih tertarik kepada dunia internet yang memberikan kemudahan dan kebahagiaan akan hal-hal yang dihadirkan oleh dunia internet. Adanya media video YouTube yang memudahkan dalam menonton secara online membuat mahasiswa lebih asyik dalam kesehariannya.

Media lainnya yang saat ini digemari mahasiswa adalah media sosial. Melalui media sosial mahasiswa akan membagikan berbagai aktivitas yang dilakukakannya bahkan aktivitas-aktivitas yang sedang viral dilakukan. Bahkan aplikasi instant messenger saat ini juga dilengkapi dengan fitur yang dapat membagikan aktivitas yang sedang dilakukan layaknya media sosial. Contohnya pada aplikasi instant messenger whatsapp yang dapat membagikan aktivitasnya kepada pengguna lain.

Walaupun media platform online menimbulkan berbagai hal negatif, masih ada mahasiswa yang memanfaatkannya. Salah satunya adalah dengan menonton video dakwah. Apalagi bagi mahasiswa, video dakwah melalui media platform online merupakan sarana yang dapat meningkatkan religiusitas yang dimiliki. Mahasiswa yang rata-rata sulit untuk membaca buku-buku yang berisikan hal-hal yang dapat meningkatkan religiusitasnya, maka menggunakan media berupa video membuatnya lebih tertarik.

Terlebih lagi dari penggunaan internet memudahkan dalam penyebaran dakwah ke seluruh dunia. Melalui media platform online, individu dapat menyebarkan dakwah dan mendapatkan informasi mengenai dakwah melalui bentuk apapun, yaitu bisa berupa video, karikatur cerita dan lain sebagainya. Perkembangan agama Islam yang disebarkan oleh Nabi Muhammad SAW dahulu dapat dilanjutkan dengan mengikuti perkembangan zaman. Perkembangan dakwah Islamiyah inilah yang menyebabkan agama Islam senantiasa berkembang dan disebarluaskan kepada masyarakat (Amin, 2013).

Saat ini terdapat beragam bentuk video maupun tulisan yang membuat mahasiswa tertarik, terlebih lagi hal-hal berupa video dakwah salah satunya dapat diakses dengan mudah dimanapun dan diwaktu kapanpun. Jadi, ketika mahasiswa yang disibukkan dengan aktivitas perkuliahan dan aktivitas lainnya, maka disela-sela kesibukkannya dapat memanfaatkan waktunya untuk meningkatkan religiusitasnya melalui video dakwah yang tersebar di akun media platform online.

Berdasarkan latar belakang yang telah penulis jelaskan di atas, maka yang menjadi permasalahan dalam penelitian ini adalah "adakah intensitas menonton video dakwah melalui media platform online dengan tingkat religiusitas pada mahasiswa?" Penelitian ini ditujukan 
untuk mengetahui derajat hubungan intensitas menonton video dakwah melalui media platform online dengan tingkat religiusitas pada mahasiswa.

\section{Metode}

Penelitian ini menggunakan pendekatan kuantitatif dengan metode korelasional yang bertujuan mengetahui sejauh mana hubungan antara satu variabel dengan satu atau lebih variabel lainnya berdasarkan koefisien korelasi (Azwar, 2015). Penelitian korelasional ini ingin mengetahui ada tidaknya hubungan atau korelasi antara intensitas menonton video dakwah melalui media platform online (X) dengan tingkat religiusitas (Y) pada mahasiswa.

Menurut Arikunto (2006) variabel merupakan objek penelitian atau bisa dikatakan sebagai hal yang menjadi titik perhatian di dalam suatu penelitian. Dalam penelitian ini variabel yang digunakan adalah Variabel independen yang sering disebut variabel stimulus, prediktor, anteseden, dan variabel bebas. Variabel ini memengaruhi atau yang menjadi sebab timbulnya variabel dependen (Sugiyono, 2013). Variabel independen dalam penelitian ini adalah intensitas menonton (X). Variabel dependen sebagai variabel output, kriteria, dan konsekuen, dan variabel terikat. Variabel ini merupakan variabel yang dipengaruhi atau yang menjadi akibat, karena adanya variabel bebas (Sugiyono, 2013). Variabel dependen dalam penelitian ini adalah religiusitas (Y).

Populasi adalah keseluruhan subjek penelitian yang akan diteliti (Arikunto, 2006). Pada penelitian ini, populasi yang dimaksud peneliti adalah mahasiswa UIN Suska Riau. Sampel adalah sebagian atau wakil dari populasi yang diteliti (Arikunto, 2006). Sampel dalam penelitian ini berjumlah 100 orang mahasiswa UIN Suska Riau. Teknik pengambilan sampel dalam penelitian ini menggunakan probability sampling dengan teknik simple random sampling. Simple random sampling merupakan teknik pengambilan sampel pada populasi yang dilakukan secara acak tanpa memperhatikan strata yang ada dalam populasi dan dilakukan apabila anggota populasi dianggap homogen (Sugiyono, 2013).

Metode pengumpulan data adalah bagian instrument pengumpulan data yang menentukan berhasil atau tidaknya suatu penelitian. Metode pengumpulan data dalam penelitian ini menggunakan skala yang berbentuk Skala Likert. Adapun skala yang digunakan dalam penelitian ini yaitu Skala Intensitas Menonton dari teori Ajzen (2005) dan Skala Religiusitas Muslim dari teori Mohd Mahudin, N. D., dkk (2016).

Hasil perhitungan reliabilitas skala intensitas menonton video dakwah dihasilkan koefisien reliabilitas sebesar 0,815 dan koefisien reliabilitas skala religiusitas sebesar 0,938. Dengan demikian skala intensitas menonton video dakwah dan skala religiusitas dapat digunakan sebagai alat ukur penelitian.

Untuk mengkaji hipotesa maka data yang diperoleh selanjutnya akan dianalisa. Analisis data yang digunakan dalam penelitian ini dengan menggunakan analisis korelasi rank spearman untuk mengetahui hubungan antara intensitas menonton video dakwah dengan tingkat religiusitas. Analisis data menggunakan bantuan program Statistical Product and Service Sollution (SPSS) 20.00 for Windows. 


\section{Hasil dan Pembahasan}

Religiusitas berasal dari bahasa latin 'ereligio' yang akar katanya adalah 'religare' yang berarti mengikat. Maksudnya adalah bahwa di dalam religi pada umumnya terdapat aturan-aturan dan kewajiban-kewajiban yang harus dilaksanakan, yang semuanya itu berfungsi untuk mengikat dan mengutuhkan diri seseorang atau sekelompok orang dalam hubungannya terhadap Tuhan, sesama manusia serta alam sekitarnya (Subandi, 2013). Kata religiusitas meskipun berasal dari akar kata religi, namun menurut Mangunwijaya (dalam Ismail, 2009) terdapat perbedaan antara religi atau agama dengan religiusitas. Religi merujuk pada aspek-aspek formal yang berkaitan dengan aturan dan kewajiban, sedangkan religiusitas merujuk pada aspek religi yang telah dihayati oleh seseorang dalam hati. Pendapat tersebut senada dengan Dister (dalam Ismail, 2009) yang mengartikan religiusitas sebagai keberagamaan karena adanya internalisasi agama tersebut dalam diri seseorang.

Glock dan Stark (dalam Ancok \& Suroso, 2004) berpendapat religiusitas adalah sistem simbol, sistem keyakinan, sistem nilai, dan sistem perilaku yang terlembagakan, yang semuanya itu berpusat pada persoalan-persoalan yang dihayati sebagai yang paling maknawi (ultimate meaning). Ancok dan Suroso (2004: 76) mengartikan religiusitas sebagai keberagamaan yang berarti meliputi berbagai macam sisi atau dimensi yang bukan hanya terjadi ketika seseorang melakukan perilaku ritual (beribadah), tapi juga ketika melakukan aktivitas lain yang didorong oleh kekuatan supranatural.

Sedangkan menurut Mohd Mahudin, dkk (2016) merujuk pada pengertian religiusitas dari sisi agama Islam itu sendiri, yaitu religiusitas menekankan pada tindakan tubuh atau aktivitas manusia (Islam), pikiran dan pemahaman tentang Allah (Iman) dan aktualisasi dari perbuatan kebaikan (Ihsan). Dimensi religiusitas yang dikemukakan oleh Mohd Mahudin, dkk (2016) juga merujuk pada pengertiannya yaitu sebagai berikut:

1) Islam, ini berupa hal-hal yang dilakukan melalui karya atau praktik keagamaan seperti ibadah dan ritual keagamaan seperti pelaksanaan salat, puasa, sedekah atau zakat, melaksanakan ibadah haji dan kewajiban sosial lainnya.

2) Iman, yaitu melibatkan pemahaman akan kepercayaan terhadap Tuhan, para Nabi,

Malaikat, Kitab Suci, dan Hari kebangkitan serta takdir baik dan buruk.

3) Ihsan, hal yang berbeda dari dimensi sebelumnya, dimensi ihsan merupakan dimensi batin dimana individu akan melakukan tindakan secara berlebihan dalam pengabdiannya kepada Allah Swt.

Meity Qodratillah (2011) mengemukakan intensitas merupakan keadaan (tingkat ukuran) kuatnya, hebatnya, bergeraknya, dan lain sebagainya. Chaplin (2011) mengungkapkan, bahwa intensity atau intensitas merupakan sifat kuantitatif dari suatu penginderaan. Sedangkan didalam kamus bahasa Indonesia, intensitas diartikan keadaan tingkat atau ukuran intensnya (artinya intensitas menonton bagi khalayak seberapa lama khalayak atau seseorang menerima pesan atau menonton (durasi), jenis tayangan apa yang khalayak terima dan tonton (konten) dan seberapa sering khalayak atau individu menghabiskan waktunya untuk menerima pesan dalam kurun waktu yang lama atau sebentar (frekuensi). Dalam konteks penelitian ini, intensitas diartikan sebagai ukuran kuantitatif dari 
berat atau kekuatan suatu tingkah laku. Ajzen (2005) membagi intensitas ke dalam empat aspek, yaitu:

1) Perhatian atau daya konsentrasi, merupakan ketertarikan terhadap objek tertentu yang menjadi target perilaku. Hal ini diilustrasikan bahwa khalayak bersifat aktif menggunakan media sesuai kebutuhan. Perhatian dalam menonton berupa tersitanya perhatian maupun waktu dan tenaga individu untuk menonton tayangan-tayangan tersebut yang disajikan di televisi.

2) Durasi, merupakan lamanya selang waktu yang dibutuhkan individu untuk melakukan perilaku atau kegiatan yang menjadi target. Durasi dalam menonton berarti membutuhkan waktu, lamanya selang waktu yang akan dibutukan untuk menonton.

3) Frekuensi atau tingkat keseringan, merupakan banyaknya pengulangan perilaku yang dilakukan untuk menjadi target pengaplikasian. Menonton dapat berlangsung dalam frekuensi yang berbeda-beda tergantung individu dalam menginginkan informasi, yaitu bisa setiap hari, bisa seminggu sekali, dua minggu sekali, bahkan sebulan sekali tergantung individu yang bersangkutan.

4) Penghayatan atau pemahaman, dapat berupa pemahaman dan penyerapan akan sesuai informasi dan kemudian informasi tersebut dipahami, dinikmati dan disimpan sebagai pengetahuan baru bagi individu yang bersangkutan.

Peneliti mengajukan hipotesis sebagai berikut, yaitu terdapat hubungan yang signifikan antara intensitas menonton video dakwah melalui media platform online dengan tingkat religiusitas pada mahasiswa.

\section{Berdasarkan Jenis Kelamin}

\section{A. Deskripsi Subjek Penelitian}

\section{Tabel 1}

\section{Deskripsi Subjek berdasarkan Jenis Kelamin}

\begin{tabular}{lcc}
\hline Jenis Kelamin & Jumlah & Presentase \\
\hline Laki-laki & 41 & $41 \%$ \\
Perempuan & 59 & $59 \%$ \\
\hline Total & 100 & $100 \%$ \\
\hline
\end{tabular}

Berdasarkan tabel 4.1 diketahui bahwa mahasiswa dalam penelitian ini sebagian besar di dominasi oleh penggemar berjenis kelamin perempuan yang berjumlah 59 orang $(59 \%)$. Kemudian penggemar berjenis kelamin laki-laki berjumlah 41 orang $(41 \%)$.

\section{Berdasarkan Usia}

\section{Tabel 2}

\section{Deskripsi Subjek berdasarkan Usia}

\begin{tabular}{lcc}
\hline Usia & Jumlah & Presentase \\
\hline 17 & 2 & $2 \%$ \\
18 & 21 & $21 \%$
\end{tabular}




\begin{tabular}{lcc}
19 & 31 & $31 \%$ \\
20 & 15 & $15 \%$ \\
21 & 15 & $15 \%$ \\
22 & 5 & $5 \%$ \\
23 & 6 & $6 \%$ \\
24 & 5 & $5 \%$ \\
\hline Total & 100 & $100 \%$ \\
\hline
\end{tabular}

Berdasarkan tabel 4.2 diketahui bahwa mahasiswa dalam penelitian ini memiliki rentang usia yang bervariasi yaitu dari berusia 17 tahun hingga berusia 24 tahun. Berdasarkan usia, subjek penelitian dapat dikelompokkan menjadi dua bagian yaitu remaja dan dewasa awal. Hal ini didasarkan pada teori yang dikemukakan oleh Papalia, Old dan Feldman (2011) yang menyebutkan bahwa rentang usia remaja adalah 12 hingga 20 tahun dan rentang usia dewasa awal adalah 21 hingga 40 tahun. Dengan demikian subjek penelitian terdiri dari 69 orang mahasiswa dengan rentang usia remaja (69\%) dan terdiri dari 31 orang mahasiswa dengan rentang usia dewasa awal (31\%).

\section{Berdasarkan Media Platform Online}

\section{Tabel 3}

Deskripsi Subjek berdasarkan Media Platform Online yang sering digunakan

\begin{tabular}{lcc}
\hline Media Platform Online & Jumlah & Presentase \\
\hline Facebook & 3 & $3 \%$ \\
Instagram & 38 & $38 \%$ \\
YouTube & 48 & $48 \%$ \\
Status Whatsapp orang lain & 11 & $11 \%$ \\
\hline Total & 100 & $100 \%$ \\
\hline
\end{tabular}

Berdasarkan tabel 4.3 diketahui bahwa mahasiswa dalam penelitian ini sebagian besar mahasiswa lebih banyak mengakses platform online untuk menonton video dakwah melalui platform YouTube yaitu 48 orang (48\%), kemudian melalui Instagram 38 orang (38\%), Status Whatsapp 11 orang (11\%) dan Facebook 3 orang (3\%).

\section{Uji Asumsi}

\section{B. Hasil Penelitian}

Uji asumsi digunakan untuk melihat apakah data yang akan dianalisis memenuhi kaidah penelitian dan memenuhi syarat agar data dapat dianalisis dengan analisis korelasi rank spearman. Ada dua uji asumsi dalam penggunaan model korelasi rank spearman yaitu uji normalitas dan uji linearitas.

Pengujian normalitas data dan linearitas data dalam penelitian ini dilakukan dengan menggunakan bantuan program Statistical Product and Service Sollution (SPSS) 20.00 for Windows. 


\section{a. Uji Normalitas}

Uji normalitas merupakan pengujian terhadap normal atau tidaknya sebaran data penelitian yang akan dianalisis. Pengujian dilakukan sebanyak variabel yang akan diolah. Pada penelitian ini, uji normalitas dilakukan terhadap dua variabel, yaitu variabel intensitas menonton $(\mathrm{X})$ dan variabel religiusitas $(\mathrm{Y})$. Data dikatakan normal jika memenuhi batas signifikansi p>0,05 (Agung, 2015).

Uji normalitas dilakukan dengan menggunakan teknik Descriptive Statistic dan dianalisis menggunakan bantuan program Statistical Product and Service Solution (SPSS) 20.00 for Windows. Hasilnya dapat dilihat pada tabel berikut:

\section{Tabel 4}

\section{Hasil Uji Normalitas}

\begin{tabular}{ccc}
\hline Variabel & Signifikansi & Keterangan \\
\hline Intensitas Menonton & 0,618 & Normal \\
Religiusitas & 0,012 & Tidak Normal \\
\hline
\end{tabular}

Berdasarkan ringkasan hasil uji normalitas pada tabel 4.5, diperoleh nilai signifikansi (Asymp.sig.) pada masing-masing variabel, yaitu variabel intensitas menonton sebesar 0,618 berdistribusi normal $(p>0,05)$ sedangkan untuk variabel religiusitas sebesar 0,012 berdistribusi tidak normal $(p<0,05)$.

\section{b. Uji Linearitas}

Uji linearitas digunakan untuk mengetahui arah, bentuk dan kekuatan hubungan antara variabel bebas dan variabel terikat. Uji linearitas dilakukan dengan ANOVA pada tes for linearity. Data linear dapat diketahui atau dilihat dari besarnya Linearity signifikansi, dimana jika signifikansi $\mathrm{p}<0,05$ dan $\mathrm{F}_{\text {hitung }}<\mathrm{F}_{\text {tabel }}$ maka hubungan variabel bebas dengan variabel terikat adalah linear.

Berdasarkan uji linearitas didapatkan hasil bahwa hubungan antara variabel intensitas menonton $(\mathrm{X})$ dengan variabel religiusitas $(\mathrm{Y})$ adalah linear dengan nilai linearity sebesar $0,000(\mathrm{p}<0,05)$.

\section{Uji Hipotesis}

Tujuan dilakukannya uji hipotesis dalam penelitian ini adalah untuk mengetahui hubungan variabel intensitas menonton video dakwah dengan variabel religiusitas. Uji hipotesis pada penelitian ini menggunakan analisis korelasi rank spearman dengan menggunakan bantuan program SPSS 20.00 for Windows. Hasil uji hipotesis dengan menggunakan teknik analisis korelasi rank spearman yaitu diperoleh nilai signifikansi sebesar 0,000 $(p<0,05)$ dan koefisien korelasi sebesar 0,494. Hipotesis yang menyatakan bahwa terdapat hubungan yang signifikan antara variabel intensitas menonton video dakwah dengan variabel religiusitas dinyatakan diterima. 


\section{Analisis Tambahan}

1. Analisis Perbedaan Berdasarkan Jenis Kelamin

Tabel 5

Uji Perbedaan Intensitas Menonton Video Dakwah dan Religiusitas Berdasarkan Jenis Kelamin

\begin{tabular}{lcccc}
\hline \multicolumn{1}{c}{ Variabel } & Jenis Kelamin & SD & $\boldsymbol{P}$ & Keterangan \\
\hline $\begin{array}{l}\text { Intensitas } \\
\text { Menonton }\end{array}$ & Laki-laki & 6,87 & 0,216 & $\begin{array}{l}\text { Tidak Ada } \\
\text { Perbedaan }\end{array}$ \\
& Perempuan & 6,58 & & \\
\hline Religiusitas & Laki-laki & 5,78 & 0,276 & $\begin{array}{l}\text { Tidak Ada } \\
\text { Perbedaan }\end{array}$ \\
& Perempuan & 4,47 & & \\
\hline
\end{tabular}

Berdasarkan tabel di atas menjelaskan bahwa tidak terdapat perbedaan intensitas menonton video dakwah dan religiusitas terhadap jenis kelamin pada mahasiswa. Hasil independent-samples T-test menunjukkan nilai signifikansi sebesar $p=0,216(\mathrm{p}>0,05)$ untuk variabel intensitas menonton video dakwah dan $p=0,276(\mathrm{p}>0,05)$ untuk variabel religiusitas.

2. Analisis Perbedaan Berdasarkan Kelompok Usia

Tabel 6

Uji Perbedaan Intensitas Menonton Video Dakwah dan Religiusitas Berdasarkan Kelompok Usia

\begin{tabular}{lcccc}
\hline \multicolumn{1}{c}{ Variabel } & Kelompok Usia & SD & $\boldsymbol{P}$ & Keterangan \\
\hline $\begin{array}{l}\text { Intensitas } \\
\text { Menonton }\end{array}$ & Remaja & 6,88 & 0,647 & $\begin{array}{l}\text { Tidak Ada } \\
\text { Perbedaan }\end{array}$ \\
& Dewasa Awal & 6,42 & & \\
\hline Religiusitas & Remaja & 4,45 & 0,348 & $\begin{array}{l}\text { Tidak Ada } \\
\text { Perbedaan }\end{array}$ \\
& & & & \\
\hline
\end{tabular}

Berdasarkan tabel di atas menjelaskan bahwa tidak terdapat perbedaan intensitas menonton video dakwah dan religiusitas terhadap kelompok usia pada mahasiswa. Hasil independent-samples T-test menunjukkan nilai signifikansi sebesar $p=0,647$ ( $p>0,05)$ untuk variabel intensitas menonton video dakwah dan $p=0,348(\mathrm{p}>0,05)$ untuk variabel religiusitas.

3. Analisis Perbedaan Berdasarkan Media Platform Online yang digunakan Tabel 7

Uji Perbedaan Intensitas Menonton Video Dakwah dan Religiusitas Berdasarkan Media Platform Online yang digunakan 


\begin{tabular}{lcccc}
\hline \multicolumn{1}{c}{ Variabel } & $\begin{array}{c}\text { Media Platform } \\
\text { Online }\end{array}$ & SD & $\boldsymbol{P}$ & Keterangan \\
\hline $\begin{array}{l}\text { Intensitas } \\
\text { Menonton }\end{array}$ & Youtube & 6,50 & 0,041 & Ada Perbedaan \\
& Instagram & 6,51 & & \\
\hline Religiusitas & Youtube & 5,41 & 0,093 & $\begin{array}{c}\text { Tidak Ada } \\
\text { Perbedaan }\end{array}$ \\
& Instagram & 4,64 & & \\
\hline
\end{tabular}

Berdasarkan tabel di atas menjelaskan bahwa terdapat perbedaan intensitas menonton video dakwah terhadap media platform online antara YouTube dan Instagram dengan nilai signifikansi sebesar $p=0,041(\mathrm{p}>0,05)$. Artinya bahwa media platform online mempengaruhi intensitas individu dalam menonton video dakwah. Hal ini dapat dilihat dari frekuensi yang ada, bahwa lebih banyak mahasiswa yang menonton video dakwah melalui platform YouTube dibandingkan Intagram. Sedangkan untuk tingkat religiusitas terhadap media platform online yang digunakan tidak terdapat perbedaan dengan nilai signifikansi sebesar $p=0,348$ ( $\mathrm{p}>0,05)$

4. Analisis Korelasi per Aspek Intensitas Menonton Video Dakwah dengan Religiusitas

Tabel 8

Korelasi per Aspek Intensitas Menonton Video Dakwah dengan Religiusitas

\begin{tabular}{lcc}
\hline \multicolumn{1}{c}{ Aspek } & $\boldsymbol{P}$ & Keterangan \\
\hline Perhatian*Religiusitas & 0,000 & Berkorelasi \\
Durasi*Religiusitas & 0,001 & Berkorelasi \\
Frekuensi*Religiusitas & 0,631 & Tidak Berkorelasi \\
Pemahaman*Religiusitas & 0,000 & Berkorelasi \\
\hline
\end{tabular}

Berdasarkan tabel di atas menjelaskan bahwa tiga dari empat aspek intensitas menonton yang berkorelasi atau berhubungan dengan variabel religiusitas. Aspek yang tidak berkorelasi dengan variabel relgiusitas adalah aspek frekuensi dimana nilai signifikansi sebesar 0,631 ( $p>0,05)$ dengan nilai koefisien korelasi sebesar 0,049. Hal ini berarti bahwa frekuensi dari menonton video tidak berpengaruh terhadap perubahan tingkat religiusitas individu. Sedangkan untuk aspek yang lainnya memiliki pengaruh terhadap tingkat religiusitas individu dimana nilai signifikansi untuk aspek perhatian sebesar 0,000 $(\mathrm{p}<0,05)$ dengan nilai koefisien korelasi sebesar 0,486 , kemudian nilai signifikansi untuk aspek durasi sebesar $0,001(\mathrm{p}<0,05)$ dengan nilai koefisien korelasi sebesar 0,337 dan nilai signifikansi untuk aspek pemahaman sebesar 0,000 $(p<0,05)$ dengan nilai koefisien korelasi sebesar 0,561. 


\section{Analisis Korelasi Intensitas Menonton Video Dakwah dengan Dimensi Religiusitas Tabel 9}

Korelasi Intensitas Menonton Video Dakwah dengan Dimensi Religiusitas

\begin{tabular}{lcc}
\hline \multicolumn{1}{c}{ Aspek } & $\boldsymbol{P}$ & Keterangan \\
\hline Intensitas*Islam & 0,000 & Berkorelasi \\
Intensitas*Iman & 0,000 & Berkorelasi \\
Intensitas*Ihsan & 0,000 & Berkorelasi \\
\hline
\end{tabular}

Berdasarkan tabel di atas menjelaskan bahwa variabel intensitas menonton berkorelasi atau berhubungan dengan masing-masing aspek religiusitas. Hal ini berarti bahwa variabel intensitas menonton video dakwah melalui media platform online memiliki pengaruh terhadap dimensi dari religiusitas individu dimana nilai signifikansi untuk dimensi islam sebesar $0,000(\mathrm{p}<0,05)$ dengan nilai koefisien korelasi sebesar 0,427 , kemudian nilai signifikansi untuk dimensi iman sebesar 0,000 ( $\mathrm{p}<0,05)$ dengan nilai koefisien korelasi sebesar 0,483 dan nilai signifikansi untuk dimensi ihsan sebesar $0,000(\mathrm{p}<0,05)$ dengan nilai koefisien korelasi sebesar 0,446.

Hasil analisis menunjukkan bahwa terdapat hubungan yang signifikan antara intensitas menonton video dakwah melalui media platform online dengan tingkat religiusitas pada mahasiswa. Hal ini berarti semakin sering individu menonton video dakwah melalui platform online maka semakin meningkat religiusitas pada dirinya.

Religiusitas sendiri sangat penting bagi individu. Glock \& Stark (dalam Ancok \& Suroso, 2011) mengatakan bahwa religiusitas adalah sistem simbol, sistem keyakinan, sistem nilai, dan sistem perilaku yang terlembagakan, yang semuanya itu berpusat pada persoalanpersoalan yang dihayati sebagai yang paling maknawi (ultimate meaning). Oleh karena itu penting religiusitas dalam hidup seseorang. Salah satu hal yang dapat meningkatkan religiusitas adalah dengan menonton video dakwah.

Seperti yang disampaikan oleh Wiryanto (2004) dalam Model Stimulus-Respon yang mengasumsikan bahwa perilaku individu karena kekuatan stimulus yang datang dari luar dirinya, bukan atas dasar motif dan sikap yang dimiliki. Model ini menjelaskan bahwa jika stimulus telah mendapatkan perhatian dari penerima maka pesan bisa diterima dan dilanjutkan ke proses selanjutnya, setelah itu penerima pesan mengelola pesan tersebut sehingga terjadi kesediaan untuk bertindak pesan yang telah diterima (sikap).

Berkaitan dengan hubungan antara intensitas menonton video dakwah melalui media platform online dengan tingkat religiusitas maka berhubungan dengan aspek intensitas menonton itu sendiri. Hasil penelitian menunjukkan bahwa aspek perhatian berhubungan dengan religiusitas. Hal ini berarti bahwa dalam menonton suatu tayangan video dakwah dibutuhkan daya konsentrasi. Individu yang konsentrasi dalam menonton tayangan dakwah tersebut akan mampu mencerna yang disampaikan pada tayangan tersebut.

Pada aspek perhatian juga dibutuhkan pengamatan. Melalui pengamatan seseorang dapat mengamati orang lain yang terlibat dalam perilaku tertentu di televisi dan dapat mempraktekkan perilaku itu dalam kehidupannya (Severin \& Tankard, 2009). Pengamatan mengajarkan individu sejumlah konsekuensi yang memungkinkan dari sebuah tingkah laku 
baru. Salah satu proses tersebut disebut dengan vicarious reinforcement (penguatan lewat pengamatan yang empatik, merasa seolah-olah diri yang melakukannya) (Crain, 2007).

Aspek durasi juga penting hubungannya dalam meningkatkan religiusitas individu. Ketika individu menonton tayangan dengan durasi yang penuh maka individu akan mampu menerima informasi secara utuh. Hal ini berbeda jika dalam menonton hanya setengah penayangan atau dalam menonton melakukan peloncatan, maka akan sulit karena tidak adanya penghayatan. Durasi sendiri merupakan salah satu faktor penting dalam hal berkomunikasi, karena agar informasi yang didapatkan tersampaikan dengan baik maka dibutuhkan durasi yang tepat, tidak lebih dan tidak kurang (Ardianto \& Komala, 2009).

Aspek dari internsitas yang berhubungan dalam meningkatnya religiusitas seseorang selanjutnya adalah aspek pemahaman. Semakin sering (intensitas) menonton maka pemahaman tentang pesan yang disampaikan juga semakin tinggi, sehingga memberikan pengaruh pada pemahaman keagamaan seseorang atau yang biasa kita kenal dengan religiusitas. Ketika individu paham akan yang dilihatnya atau yang ditontonnya maka individu paham akan informasi yang disampaikan sehingga individu mampu dalam mengaplikasikan dalam kehidupannya (Bandura dalam Inayah, 2011).

Hal yang dilihat selanjutnya adalah mengenai hubungan antara intensitas terhadap dimensi pada religiusitas. Hasil penelitian menunjukkan bahwa intensitas berhubungan dengan seluruh dimensi dari religiusitas yaitu Islam, Iman, dan Ihsan. Artinya, intensitas menonton video dakwah melalui media platform online dapat memengaruhi religiusitas seseorang baik dari segi keislaman, keimanan dan keihsanan.

Seperti dalam Hadits Rasulullah Saw. yang artinya "Maksudnya: Dari Abu Hurairah berkata; bahwa Nabi SAW pada suatu hari muncul kepada para sahabat, lalu datang Malaikat Jibril 'Alaihis Salam yang kemudian bertanya: "Apakah iman itu?" Nabi SAW menjawab: "Iman adalah kamu beriman kepada Allah, malaikat-malaikat-Nya, kitab-kitab-Nya, pertemuan dengan-Nya, Rasul-Rasul-Nya, dan kamu beriman kepada hari berbangkit". (Jibril 'Alaihis salam) berkata: "Apakah Islam itu?" Jawab Rasulullah SAW "Islam adalah kamu menyembah Allah dan tidak menyekutukannya dengan suatu apapun, kamu dirikan shalat, kamu tunaikan zakat yang diwajibkan, dan berpuasa di bulan Ramadlan". (Jibril 'Alaihis salam) berkata: "Apakah ihsan itu?" Nabi SAW menjawab: "Kamu menyembah Allah seolaholah melihat-Nya dan bila kamu tidak melihat-Nya sesungguhnya Dia melihatmu". (HR AlBukhari, 1987: 50; Muslim, t.th: 9)."

Secara umumnya, hadis ini membicarakan tentang kesempurnaan agama Islam dengan menyebutkan terdapat tiga komponen yang menjadi asas dalam Islam yang mencakupi seluruh aspek kehidupan manusia yang terkandung di dalamnya ibadah yang menjadi tujuan hidup manusia. Komponen tersebut adalah. Iman, Islam dan ihsan.

Hasil penelitian selanjutnya menunjukkan bahwa diantara tiga dimensi tersebut yang paling besar koefisien korelasi adalah pada dimensi iman. Hal ini berarti bahwa iman merupakan dimensi yang paling dipengaruhi dalam meningkatnya religiusitas individu. Ketika dimensi iman telah dipengaruhi maka dimensi yang lain juga mengikuti. Natijah dari iman, Islam dan ihsan yang diyakini dan diamalkan menghasilkan rasa tenang, aman dan bahagia. Sebaliknya jika ketiga-ketiga prinsip ini tidak diyakini atau diyakini tanpa amalan 
yang mempamerkan keyakinan yang dipegang, tidak akan menghasilkan kesan yang positif kepada jiwa seseorang.

Hasil analisis perbedaan menunjukkan bahwa tidak terdapat perbedaan antara intensitas menonton video dakwah dan religiusitas berdasarkan jenis kelamin. Hal ini menjelaskan bahwa baik laki-laki maupun perempuan tidak memiliki perbedaan dalam intensitas untuk menonton video dakwah dan juga baik laki-laki dan perempuan tidak ada perbedaan dalam tingkatan religiusitasnya. Laki-laki dan perempuan bisa sama-sama memiliki religiusitas yang rendah maupun tinggi tergantung dari individu itu sendiri. Sesuai dengan firman Allah Swt dalam Surah Ali Imran ayat 195 yang artinya "Maka Tuhan mereka memperkenankan permohonannya (dengan berfirman): "Sesungguhnya Aku tidak menyia-nyiakan amal orangorang yang beramal di antara kamu, baik laki-laki atau perempuan, (karena) sebagian kamu adalah turunan dari sebagian yang lain. Maka orang-orang yang berhijrah, yang diusir dari kampung halamannya, yang disakiti pada jalan-Ku, yang berperang dan yang dibunuh, pastilah akan Ku-hapuskan kesalahan-kesalahan mereka dan pastilah Aku masukkan mereka ke dalam surga yang mengalir sungai-sungai di bawahnya, sebagai pahala di sisi Allah. Dan Allah pada sisi-Nya pahala yang baik".

Hasil analisis perbedaan selanjutnya menunjukkan bahwa tidak terdapat perbedaan antara intensitas menonton video dakwah dan religiusitas berdasarkan kelompok usia yaitu remaja dan dewasa awal. Hal ini berarti tidak membedakan tinggi rendahnya intensitas dalam menonton video dakwah baik individu remaja maupun individu dewasa awal. Hal ini juga berarti bahwa tidak membedakan tingkat religiusitas antara individu remaja dengan individu dewasa awal, bisa jadi individu remaja bisa lebih tinggi religiusitasnya dibanding individu dewasa awal ataupun sebaliknya dan bahkan setara tingkat religiusitasnya.

Hasil analisis perbedaan lainnya menunjukkan bahwa terdapat perbedaan antara intensitas menonton video dakwah berdasarkan media platform online yang dgunakan. Hal ini berarti bahwa media platform online memengaruhi intensitas menonton dakwah individu. Berdasarkan frekuensi yang diperoleh, mahasiswa lebih tertarik menonton secara intens melalui media platform online Youtube dibanding dengan media platform online Instagram. Sedangkan analisis perbedaan religiusitas berdasarkan media platform online yang digunakan adalah tidak terdapat perbedaan yang signifikan. Hal ini berarti video dakwah dari media paltform online manapun yang ditonton oleh mahasiswa tidak membedakan tingkat religiusitasnya. Sehingga dapat ditarik kesimpulan bahwa melalui media platform online apapun mahasiswa menonton video dakwah bisa meningkatkan religiusitasnya, namun tergantung dengan bagaimana intensitas menonton itu dilakukan.

\section{Simpulan}

Hasil penelitian dapat disimpulkan bahwa terdapat hubungan antara intensitas menonton video dakwah melalui media platform online dengan tingkat religiusitas pada mahasiswa. Hal ini ditunjukkan dengan nilai signifikansi $\mathrm{p}=0,000 \quad(\mathrm{p}<0,05)$ dan nilai koefisien korelasi sebesar 0,494. Artinya, semakin sering atau semakin intens seseorang menonton video dakwah melalui media platform online maka semakin tinggi religiusitas yang dimiliki oleh individu tersebut. Jadi, menonton video dakwah melalui media platform 
online dapat menjadi salah satu cara atau usaha dalam meningkatkan religiusitas pada diri individu.

Hasil lainnya adalah hubungan atau korelasi per aspek dari aspek intensitas menonton dengan religiusitas. Terdapat hubungan antara aspek penghayatan, durasi dan pemahaman dengan religiusitas pada individu sedangkan aspek frekuensi tidak berhubungan dengan religiusitas. Artinya aspek penghayatan, durasi dan pemahaman memberikan pengaruh terhadap meningkatnya religiusitas pada individu, sedangkan aspek frekuensi tidak memberikan pengaruhnya.

Hasil lainnya juga disimpulkan bahwa tidak terdapat perbedaan intensitas menonton video dakwah melalui media platform online antara laki-laki dan perempuan juga antara individu remaja dan individu dewasa awal. Begitu pula dengan religiusitas yang tidak memiliki perbedaan antara laki-laki dan perempuan juga antara individu remaja dan individu dewasa awal dan juga tidak terdapat perbedaan melalui media platform online manapun tingkat religiusitas individu namun terdapat perbedaan intensitas menonton yang dilakukan pada media platform online yang digunakan, yaitu antara media platform online Youtube dan Instagram.

\section{Referensi}

Ajzen, I. (2005). Attitude, Personality, and Behaviour. New York: Open University Press Al-Quran dan Terjemahannya. (2014). Departemen Agama RI. Jakarta: Al-Fatih.

Agung, Ivan Muhammad. (2015). Modul Pelatihan SPSS. Pekanbaru: Fakultas Psikologi Universitas Islam Negeri Sultan Syarif Kasim Riau.

Amin, Samsul Munir. 2013. Ilmu Dakwah. Jakarta : Amzah

Ancok, D \& Suroso, F. N. (2004). Psikologi Islam. Yogyakarta: Pustaka Belajar

Ardianto, E., Karlinah, S. \& Komala, L. (2009). Komunikasi Massa Suatu Pengantar. Bandung: Simbiosa Rekatama Media

Arikunto. (2006). Prosedur Penelitian Suatu Pendekatan Praktek. Jakarta: PT. Rineka Cipta

Azwar, Saifuddin. (2015). Metode Penelitian. Yogyakarta: Pustaka Pelajar

Caplin, J. (2011). Kamus Lengkap Psikologi. Jakarta: Rajagrafindo Persada

Crain, W. (2007). Teori perkembangan. Yogyakarta: Pustaka Pelajar

Darajat, Z. (2003). Ilmu Jiwa Agama. Jakarta: Bulan Bintang

Inayah. (2011) Tinjauan Psikologis Efek Komunikasi Massa. Jurnal Pengembangan Humaniora. 11, 3, $168-173$.

Ismail, W. (2009). Analisis Komparatif Perbedaan Tingkat Religiusitas Siswa di Lembaga Pendidikan Pesantren, MAN dan SMUN. Jurnal Lentera Pendidikan, 12 (1) : 87-102

Muslim, A. H. (n.d.). Sahih Muslim. Beirut: Dar Ihya Al-Thurath Al-Araby

Mohd Mahudin, N. D., Mohd Noor, N., Dzulkifli, M. A., \& Janon, N. S. (2016). Religiosity among muslims: A scale development and validation study. Makara Hubs-Asia, 20(2): $109-121$

Papalia, D. E., Old, S. W. \& Feldman, R. D. (2011). Human Development: Psikologi Perkembangan Bagian V s.d. IX. Jakarta: Kencana Prenada Media Grup

Qodratilah, M. T. (2011). Kamus Bahasa Indonesia untuk Pelajar. Jakarta: Badan Pengembangan dan Pembinaan Bahasa Kementrian Pendidikan dan Kebudayaan.

Sarwono, S. W. (2011). Psikologi Remaja. Jakarta: Rajawali Press

Severin, W J \& Tankard, J W. 2009. Teori Komunikasi. Kencana: Jakarta. 
Sikape, Harvey J. (2014). Persepsi Komunikasi Pengguna Media Sosial Pada Blackberry Messenger, Twitter dan Facebook oleh Siswa SMA N 1 Tahuna. Journal "Acta Diurna"Volume III. No.3

Soetjipto, Helly P. (2005). Pengujian Validitas Konstruk Kriteria Kecanduan Internet. Jurnal Psikologi Universitas Gadjah Mada Volume 32, No. 2, 74-91

Subandi, M. A. (2013). Psikologi Agama dan Kesehatan Mental. Yogyakarta: Pustaka Pelajar Sugiyono. (2013). Metode Penelitian Kuantitatif Kualitatif dan R\&D. Bandung: Alfabeta Wiryanto. (2004). Pengantar Ilmu Komunikasi. Jakarta: Gramedia 